Jurnal BASTRA (Bahasa dan Sastra) : http://ojs.uho.ac.id/index.php/BASTRA

\title{
KEMAMPUAN MENULIS TEKS BIOGRAFI TOKOH SISWA KELAS X SMA NEGERI 1 LEMBO
}

\author{
OLEH \\ Milawati $^{1}$, Amirudin Rahim ${ }^{2}$, Marwati ${ }^{3}$ \\ ${ }^{1}$ Alumni Jurusan Pend. Bahasa dan Sastra Indonesia, ${ }^{2,3}$ Dosen Jurusan Pendidikan \\ Bahasa dan Sastra Indonesia, Fakultas Keguruan dan Ilmu Pendidikan \\ Universitas Halu Oleo
}

\begin{abstract}
ABSTRAK
Penelitian ini bertujuan untuk mengetahui kemampuan menulis teks biografi tokoh siswa kelas X SMA Negeri 1 Lembo. Metode yang digunakan dalam penelitian ini adalah metode lapangan. Jenis penelitian adalah deskripsi kuantitatif. Populasi dalam penelitian adalah keseluruhan siswa kelas X SMA Negeri 1 Lembo tahun ajaran 2018/2019. Populasi tersebut dalam empat kelas, maka penarikan sampel dalam penelitian ini adalah seluruh siswa kelas X SMA Negeri 1 Lembo yang berjumlah 81. Berdasarkan hasil analisis data menunjukan bahwa kemampuan menulis teks biografi siswa kelas X SMA Negeri 1 Lembo terdapat dalam kategori tidak mampu secara klasikal dengan persentase kemampuan $80,24 \%$. Bila dilihat pada setiap aspek yang telah diteliti sebagai berikut, struktur orientasi $98,76 \%$, struktur proses kejadian 98,76\%, struktur reorientasi 98,76\%, kebahasaan pronominal $56,79 \%$, kebahasaan kata kerja tindakan $60,49 \%$, kebahasaan kata adjaktiva 62,93\%, kebahasaan kata kerja pasif 9,78\%, kebahasaan kata kerja aktivitas 14,81\%, kebahasaan konjungsi kausalitas/konjungsi kronologis 93,82\%.
\end{abstract}

Kata Kunci: kemampuan, menulis, teks biografi 


\section{PENDAHULUAN}

\subsection{Latar Belakang}

Pembelajaran bahasa indonesia secara umum diarahkan untuk meningkatkan kemampuan berkomunikasi para siswa. Kemampuan berkomunikasih siswa yang dimaksud adalah menggunakan bahasa indonesia dengan baik dan benar, baik secara lisan maupun tulisan. Dalam hal ini, guru harus mampu menggambarkan penguasaan pengetahuan, keterampilan berbahasa, dan sikap positif terhadap bahasa indonesia.

Pendidikan merupakan suatu kebutuhan yang penting dalam kehidupan. Melalui pendidikan akan diperoleh pengetahuan dan keterampilan untuk pembentukan kepribadian, baik melalui bimbingan dan pengarahan dari orang tua atau guru. Salah satu jenis pendidikan yang bisa ditempuh adalah pendidikan formal. Pendidikan formal merupakan pendidikan yang terstruktur dan berjenjang yang terdiri atas pendidikan dasar, pendidikan menengah, dan pendidikan tinggi.

Pembelajaran saat ini berpedoman pada Kurikulum 2013. Kurikulum 2013 merupakan langkah lanjutan pemerintah dalam mengembangkan aspek yang disempurnakan dalam Kurikulum 2013 adalah standar kompetensi lulusan (SKL), kompetensi inti (KI), kompetensi dasar (KD). Selanjutnya akan dijelaskan mengenai keterkaitan antara SKL, KI, dan KD. SKL yaitu standar kompetensi lulusan merupakan profil lulusan yang diimplikasikan untuk dimiliki setiap siswa ketika ia lulus dari suatu jenjang pendidikan baik (SD, SMP, SMA). Dalam SKL terdapat tiga ranah yaitu sikap, pengetahuan, dan keterampilan. Setelah SKL dikembangkan disusunlan kompetensi inti yang merupakan jabaran lebih lanjut. SKL untuk sikap dipilih menjadi dua KI, yaitu terkait dengan sikap spiritual (KI-1) dan sikap sosialnya (KI-2). SKL pengetahuan dijabarkan menjadi KI pengetahuan (KI-3) dan SKL keterampilan dijabarkan menjadi KI keterampilan(KI-4) (Priyatni, 2017:20).

Pembelajaran bahasa indonesia memiliki empat aspek keterampilan berbahasa yang meliputi empat keterampilan berbahasa yang diterima oleh seseorang secara berurutan. Keterampilan tersebut adalah menyimak, berbicara, membaca, dan menulis. Di antara keempat keterampilan berbahasa tersebut, menulis merupakan keterampilan tertinggi yang dimiliki oleh seseorang. Keterampilan menulis diterima seseorang setelah dia mampu membaca. Seorang siswa di kelas awal tentunya belajar membaca terlebih dahulu sebelum belajar menulis.

Sebagaiman pendapat Suparno (2007: 1.29), menulis merupakan suatu kegiatan komunikasi berupa penyampaian pesan secara tertulis kepada pihak lain. Aktivitas menulis melibatkan unsur penulis sebagai penyampaian pesan, pesan atau isi 
tulisan, saluran atau media tulisan, dan pembaca sebagai penerima pesan. Selanjutnya Suparno (2007: 1.29) menulis merupakan kegiatan yang kompleks karena penulis dituntut untuk dapat menyusun dan mengorganisasikan isi tulisannya serta menuangkannya dalam formulasi ragam bahasa tulis dan konvensi penulisan lainnya. Dan menulis sebagai aktivitas berbahasa tidak dapat dilepas dari kegiatan berbahasa lainnya.

Kegiatan menulis sangat penting dalam pendidikan karena dapat membantu siswa berlatih berpikir, mengungkapkan gagasan, dan memecahkan masalah. Menulis adalah salah satu bentuk berpikir, yang juga merupakan alat untuk membuat orang lain (pembaca) berpikir. Dengan menulis, seorang siswa mampu mengkonstruk berbagai ilmu atau pengetahuan yang dimiliki dalam sebuah tulisan, baik dalam bentuk esai, artikel, laporan ilmiah, cerpen, puisi, dan sebagainya, Rasidik (2009: 3).

Teks biografi adalah teks yang menceritakan perjalanan hidup tokoh dan memiliki pesan atau nilai keteladanan bagi pembacanya. Menulis teks biografi memiliki tujuan untuk mengapresiasi perjalanan hidup tokoh dan memotivasi siswa untuk menjadi pribadi yang lebih baik sesuai dengan pendidikan karakter dalam Kurikulum 2013. Teks biografi merupakan salah satu materi ajar yang dapat meningkatkan keterampilan menulis pada siswa.
Kuntowijoyo (dalam Sari, dkk. 2003:207), mengatakan bahwa sehubungan dengan kepribadian tokoh,sebuah biografi perlu memperhatikanadanya latar belakang keluarga, pendidikan, lingkungan sosial budaya dan perkembangan diri. Dalam pembelajaran bahasa Indonesia, pembelajaran menulis teks biografi menjadi sangat penting karena dapat merangsang siswa untuk gemar menulis dan tentunya akan meningkatkan kemampuan siswa dalam penggunaan bahasa Indonesia yang baik dan benar.

Pengertian teks dalam kurikulum ini berbeda dengan pengertian teks selama ini. Teks selama ini diartikan sebagai wacana tertulis. Berdasarkan kurikulum2013 tekstidak diartikan sebagai bentuk bahasa tulis. Teks adalah ungkapan pikiran manusia yang lengkap yang di dalamnya ada situasi dan konteksnya. Teks dibentuk oleh konteks situasi penggunaanbahasa yang di dalamnya ada Register atau ragam bahasa yang melatarbelakangi lahirnya teks tersebut

Berdasarkan hasil wawancara yang dilakukan dengan Harnati, S.Pd. selaku guru mata pelajaran bahasa Indonesia SMA Negeri 1 Lembo, diketahui bahwa nilai mata pelajaran bahasa Indonesia siswa kelas X pada tahun pelajaran 2018/2019 bervariasi antara 75-95 dari nilai ujian sekolah. Kegiatan tes dan praktik yang telah di lakukan di sekolah, menunjukkan bahwa hasil kerja siswa cukup baik. Dalam proses menulis teks biografi 
tokoh sangat diperlukan ketelitian siswa, karena siswa diajak untuk berpikir dan kreatif dalam menyusun teks biografi menjadi sebuah ringkasan. Dalam menulis isi teks biografi siswa diharapkan mampu memahami tentang bagaimana menulis isi teks biografi dengan memperhatikan kesesuaian dengan struktur dan kebahasaan teks biografi.

Berdasarkan hal tersebut maka akan dilakukan penelitian tentang "Kemampuan Menulis Teks Biografi Tokoh Siswa Kelas X SMA Negeri 1 Lembo".

\section{METODE DAN TEKNIK PENELITIAN}

\subsection{Jenis Penelitian}

Jenis penelitian yang digunakan dalam penelitian ini adalah deskriptif kuantitatif, yaitu mengambarkan secara objektif hasil yang diperoleh siswa dalam menulis teks biografi tokoh dalam menggunakan angkaangka sesuai dengan prinsip statistik yang digunakan dalam penelitian ini.

\subsection{Metode Penelitian}

Metode yang digunakan dalam penelitian ini adalah metode penelitian lapangan , yakni peneliti turun langsung ke lokasi penelitian untuk mengumpulkan data penelitian di kelas X SMA Negeri 1 Lembo.

\subsection{Populasi Penelitian}

Populasi adalah wilayah generalisasi yang terdiri atas: objek/subjek yang mempunyai kualitas dan karakteristik tertentu yang ditetapkan oleh peneliti untuk dipelajari dan kemudian ditarik kesimpulannya (Sugiyono,2016:80).

Populasi dalam penelitian ini adalah keseluruhan siswa kelas $\mathrm{X}$ SMA Negeri 1 Lembo tahun pelajaran 2018/2019 dengan jumlah siswa 81 orang. Berdasarkan observasi awal bahwa skor nilai mata pelajaran bahasa Indonesia siswa bervariasi antara 75-95 dari nilai ujian sekolah. Dengan demikian karakteristik dalam penelitian ini bersifat heterogen. Adapun gambaran populasi penelitian dapat dilihat pada tabel berikut ini.

Tabel Populasi Siswa Kelas X SMA Negeri 1 Lembo Tahun Ajaran 2018/2019.

\begin{tabular}{|l|l|l|}
\hline No & Kelas & $\begin{array}{l}\text { Jumlah } \\
\text { (populasi) }\end{array}$ \\
\hline 1 & X MIA $^{1}$ & 21 \\
\hline 2 & X MIA $^{2}$ & 19 \\
\hline 3 & X IIS $^{1}$ & 20 \\
\hline 4 & X IIS $^{2}$ & 21 \\
\hline \multicolumn{2}{|l|}{$\begin{array}{l}\text { Jumlah } \\
\text { keseluruhan }\end{array}$} & 81 \\
\hline
\end{tabular}

\subsection{Sampel Penelitian}

Sampel adalah bagian dari jumlah dan karakteristik yang dimiliki oleh populasi tersebut. Bila populasi besar dan peneliti tidak mungkin mempelajari semua yang ada pada populasi, misalnya karena keterbatasan dana, tenaga, dan waktu, maka peneliti dapat menggunakan sampel yang diambil dari populasi itu 
(Sugiyono, 2016: 81). Hal ini didukung oleh teori dariArikunto (2002: 112) menyatakan bahwa apabila subjeknya kurang dari 100 , lebih baik diambil semua sehingga penelitiannya merupakan penelitian populasi. Selanjutnya, jika jumlah subjeknya besar dapat diambil antara $10-15 \%$ atau $20-25 \%$ atau lebih. Dengan demikian yang menjadi sampel dalam penelitian ini adalah seluruh siswa kelas X SMA Negeri 1 Lembo Kab. Konawe utara tahun ajaran 2018/2019 yang berjumlah 81 siswa.

\subsection{Instrumen Penelitian}

Djaali (dalam Matodang, 2009:87) menyatakan bahwa secara umum yang dimaksud dengan instrumen adalah suatu alat yang karena memenuhi persyaratan akademik maka dapat dipergunkan sebagai alat untuk mengukur suatu obyek ukur atau mengumpulkan data mengenai suatu variable.

Instrumen yang digunakan dalam penelitian ini adalah tes esai.Tes ini digunakan untuk mengukur kemampuan siswa dalam menulis tek biografi tokoh, siswa diberi tugas menulis teks biografi tokoh terlebih dahulu, siswa menulis teks biografi tokoh berdasarkan topik yang telag dipilih. Tes ini dilakukan dalam satu kali pertemuan selama 90 menit atau $2 \times 24$ menit (2 jam pelajaran).
Topik-topik yang dapat dipilih siswa antara lain sebagai berikut :

a. Bj Habibi

b. Ki Hajar Dewantara Instrumen memenuhi validaritas isi kurikulum 2013, sebab dalam silabus mata pelajaran bahasa indonesia kelas X semester 2 SMA, kurikulum 2013, tercantum materi pembelajaran menulis teks biografi tokoh.

\subsection{Teknik Pengmpulan Data}

Teknik pengumpulan data merupakan langkah yang paling strategis dalam penelitian, karena tujuan utama dari penelitian adalah mendapatkan data (Sugiyono 2016:224). Untuk memperoleh data yang diinginkan maka alat yang digunakan adalah tes esai. Menurut Djiwandono (1996:25) tes esai mewajibkan pesertanya untuk melakukan tugas atau memberikan jawaban tesnya dalam bentuk esai, yaitu karangan atau karya tulis. Adapun langkah-langkah yang digunakan penggumpulan data dilakukan sebagai berikut:

1. Mengumpulkan siswa dalam ruang kelas.

2. Siswa menyiapkan alat-alat tulis yang mendukung kegiatan menulis.

3. Membagikan instrumen kepada siswa.

4. Memberikan kesempatan kepada siswa untuk bertanya tentang petunjuk instrumen. 
5. Siswa menuliskan identitas dan memberi nomor urut pada lembar kerja.

6. Siswa diberi kesempatan untuk menulis teks biografi.

7. Setelah waktu yang diberikan selesai, lembar kerja siswa dikumpulkan.

8. Memeriksa lembar kerja siswa.

\subsection{Teknik Penilaian}

Teknik untuk menilai tulisan siswa adalah teknik analitik, yaitu penilaian berdasarkan unsur-unsurnya. Skala yang dipakai untuk menilai tulisan adalah skala penilaian 1-4. Skala tersebut mengacu pada pedoman dan penskoran kemampuan meringkas bahasa Indonesia yang ditetapkan oleh Kementerian Pendidikan dan Kebudayaan (2017) sebagai berikut:

Pertama struktur penulisan biografi terdiri atas 3 bagian yaitu orientasi, proses kejadian, dan reorientasi. Apabila tulisan siswa terdapat 3 penggunaan orientasi, proses kejadian, dan reorientasi dengan tepat skor 4. Apabila tulisan siswa terdapat 2 penggunaan orientasi proses kejadian, dan reorientasi dengan tepat skor 3. Apabila tulisan siswa terdapat 1 penggunaan orientasi proses kejadian, dan reorientasi dengan tepat skor 2. Apabila tulisan siswa tidak terdapat penggunaan orientasi proses kejadian, dan reorientasi dengan tepat skor 1 . Kedua kebahasaan teks biografi yang terdiri dari kata pronominal, kata kerja tindakan, kata adjektiva, kata kerja pasif, kata kerja aktivitas, dan kata kerja konjungsi kausaliatas/konjungsi kronologis. . Apabila tulisan siswa terdapat 3 penggunaan kata pronominal, kata kerja tindakan, kata adjektiva, kata kerja pasif, kata kerja aktivitas, dan kata kerja konjungsi kausaliatas/konjungsi kronologis dengan tepat skor 4. Apabila tulisan siswa terdapat 2 penggunaan kata pronominal, kata kerja tindakan, kata adjektiva, kata kerja pasif, kata kerja aktivitas, dan kata kerja konjungsi kausaliatas/konjungsi kronologis dengan tepat skor 3 . Apabila tulisan siswa terdapat 1 penggunaan kata pronominal, kata kerja tindakan, kata adjektiva, kata kerja pasif, kata kerja aktivitas, dan kata kerja konjungsi kausaliatas/konjungsi kronologis dengan tepat skor 2. Apabila tulisan siswa tidak terdapat penggunaan kata pronominal, kata kerja tindakan, kata adjektiva, kata kerja pasif, kata kerja aktivitas, dan kata kerja konjungsi kausaliatas/konjungsi kronologis dengan tepat skor 1 .

\subsection{Teknik Analisis Data}

Analisis data penelitian ini menggunakan deskriptif kuantitatif yaitu analisis berdasarkan presentase. Analisis deskriptif dimaksudkan untuk menggambarkan hasil penelitian berdasarkan kenyataan objektif yang diperoleh di lapangan yaitu berupa hasil tes menulis teks biografi tokoh siswa kelas X SMA Negeri 1 Lembo. Penggunaan rancangan kuantitatif berdasarkan pertimbangtan bahwa apa yang dianalisis dalam hubungan 
antara satu dengan yang lain didukung oleh angka-angka.

Siswa dikatakan mampu secara individual apabila mempunyai kemampuan minimal 75 dari setiap aspek yang dinilai dan secara klasikal harus mencapai $85 \%$.Hal ini berdasarkan KKM yang terdapat di SMA Negeri 1 Lembo Kab. Konawe Utara. Oleh sebab itu, akan digunakan untuk mengetahui ketuntasan belajar siswa secara individual dan secara klasikal. Rumus yang digunakan untuk menentukan nilai setiap responden dalam menulis teks biografi tokoh adalah sebagai berikut:

$\mathrm{KI}=\frac{\text { Skor Perolehan Siswa }}{\text { Skor Maksimal }} \mathrm{X} 100 \%$

Ket: $\mathrm{KI}=$ Ketuntasan Individual

(Sumber:SMA Negeri 1 Lembo)

Rumus yang dipakai untuk menentukan kemampuan siswa klasikal adalah:

KK

$=\frac{\sum \text { Siswa yang Secara Individual Memperoleh Presentase } \geq 75 \%}{\text { Jumlah keseluruhan siswa }} \mathrm{X} 100$

Ket: KK= Ketuntasan Klasikal

(Sumber:SMA Negeri 1 Lembo)

Dari presentase yang diperoleh, baik untuk kemampuan siswa secara individual maupun secara leksikal selanjutnya diacukan pada penilaian yang telah ditetapkan untuk menentukan kemampuan siswa.Untuk lebih jelasnya dapat dilihat pada tabel 3 berikut:

Tabel Rentang Kemampuan

\begin{tabular}{|l|l|l|}
\hline $\begin{array}{l}\text { Rentang } \\
\text { Kemampuan }\end{array}$ & $\begin{array}{l}\text { Rentang } \\
\text { Skor }\end{array}$ & $\begin{array}{l}\text { Presentase } \\
\text { Kemampuan } \\
(\%)\end{array}$ \\
\hline Mampu & $27-36$ & $75-100 \%$ \\
\hline Tidak mampu & $1-26$ & $2-73 \%$ \\
\hline
\end{tabular}

Dari tabel tersebut dapat dijelaskan sebagai berikut :

1. Siswa dikategorikan mampu menulis teks biografi tokoh jika mendapat skor antara 27-36 dengan presentase $75-100 \%$.

2. Siswa dikategorikan tidak mampu menulis teks biografi tokoh jika mendapat skor antara 1-26 dengan presentase $2-73 \%$.

\section{HASIL DAN PEMBAHASAN}

Berdasarkan hasil deskripsi pada table 4, dapat dikemukakan sebagai berikut:

1. Sebanyak 65 siswa atau $80,24 \%$ tergolong kategori mampu meringkas isi teks eksplanasi dengan rincian, 3 siswa memperoleh 97,2\%, 1 siswa memperoleh $94,4 \%, 8$ siswa memperoleh $83,3 \%, 9$ siswa memperoleh $80,5 \%, 25$ siswa memperoleh 77,7\%, dan 19 siswa memperoleh $75 \%$.

2. Sebanyak 16 siswa atau $\%$ memperoleh kategori tidak mampu menulis teks biografidengan rincian, 8 siswa memperoleh 72,2\%, 16 siswa memperoleh 69,4\%, 15 siswa memperoleh $66,6 \%$, 4 siswa memperoleh $61,1 \%, 2$ siswa memperoleh $58,3 \%, 5$ siswa memperoleh 55,5\%, 1 siswa memperoleh $52,7 \%$, dan 1 siswa memperoleh $36,1 \%$. 
Untuk mendapatkan gambaran yang jelas tentang perolehan skor dalam rentang kategori kemampuan menulis teks biografi tokoh siswa kelas X SMA Negeri 1 Lembo, maka dapat dilihat pada tabel persentase kemampuan berikut ini.

Tabel Persentase Keseluruhan Aspek Penilaian Kemampuan Menulis Teks Biografi Tokoh Siswa Kelas X SMA Negeri 1 Lembo

\begin{tabular}{|l|l|l|l|}
\hline No & Kategori & Frekuensi & Persentase \\
\hline 1 & Mampu & 65 & $80,24 \%$ \\
\hline 2 & $\begin{array}{l}\text { Tidak } \\
\text { mampu }\end{array}$ & 16 & $19,75 \%$ \\
\hline \multicolumn{2}{|l|}{ Jumlah } & 81 & $100 \%$ \\
\hline
\end{tabular}

Berdasarkan tabel di atas, dapat diperoleh data bahwa dari siswa yang dijadikan sampel terdapat 65 siswa $(80,24 \%)$ memperoleh kategori mampu, 16 siswa $(19,75 \%)$ yang tergolong tidak mampu.

Selanjutnya untuk mengukur kemampuan menulis teks biografi tokoh siswa kelas X SMA Negeri 1 Lembo secara klaksikal maka digunakan rumus sebagai berikut.

$$
\begin{aligned}
K K & =\frac{65}{81} \times 100 \\
& =80,24 \%
\end{aligned}
$$

Dengan demikian, kemampuan menulis teks biografi tokoh siswa kelas X SMA Negeri 1 Lembo dikategorikan tidak mampu secara klaksikal. Dikatakan tidak mampu karena kemampuan siswa dalam menulis teks biografi tokoh secara keseluruhan tidak mencapai $85 \%$ standar kemampuan secara keseluruhan yang ditetapkan. Siswa dikatakan mampu secara keseluruhan bila rata-rata siswa yang memperoleh nilai di atas Kriteria Ketuntasan Minimal (75) mencapai 85\%.

\subsection{Deskripsi Kemampuan Menulis} Teks Biografi Tokoh Siswa Kelas X SMA Negeri 1 Lembo Pada Setiap Aspek

\subsubsection{Kemampuan Menulis Teks} Biografi Tokoh Pada Aspek Struktur Teks Biografi (Orientasi)

Berdasarkan tabel diatas, hasil pengolahan data tentang kemampuan menulis teks biografi pada aspek struktur teks biografi (orientasi) menunjukkan bahwa dari 81 siswa kelas X SMA Negeri 1 Lembo , sebanyak 80 siswa masuk kategori mampu dengan rincian 79 siswa memperoleh skor 4 dan 1 siswa memperoleh skor 3. Sedangkan 1 siswa masuk kategori tidak mampu dengan rincian memperoleh skor 1 .

Tabel Persentase Perolehan Kemampuan Menulis Teks Biografi Tokoh Siswa Kelas X SMA Negeri 1 Lembo pada Aspek Struktut Teks Biografi (Orientasi)

\begin{tabular}{|l|l|l|l|}
\hline No & Kategori & $\begin{array}{l}\text { Fre } \\
\text { kuensi }\end{array}$ & $\begin{array}{l}\text { Per } \\
\text { sentase }\end{array}$ \\
\hline 1. & Mampu & 80 & $98,76 \%$ \\
\hline 2. & $\begin{array}{l}\text { Tidak } \\
\text { mampu }\end{array}$ & 1 & $1,23 \%$ \\
\hline \multicolumn{2}{|c|}{ Jumlah } & 81 & $100 \%$ \\
\hline
\end{tabular}

Selanjutnya untuk mengukur kemampuan menulis teks biografi tokoh pada aspek srtuktur teks biografi orientasi secara klasikal maka digunakan rumus sebagai berikut. 
$K K=$
$\frac{\text { Jumlah siswa yang secara individual memperoleh persentase } \geq 75}{\text { Jumlah keseluruhan siswa }} \times 100 \%$
$K K=\frac{80}{81} \times 100=98,76 \%$

Berdasarkan persentase tersebut, dapat dikatakan bahwa siswa kelas $\mathrm{X}$ SMA Negeri 1 Lembo mampu menulis teks biografi pada aspek struktur teks biografi (orientasi). Dikatakan mampu, karena kemampuan siswa mencapai 98,76\% atau lebih dari batas kemampuan secara klasikal $75 \%$.

\subsubsection{Kemampuan Menulis Teks \\ Biografi Tokoh pada Aspek Struktur Teks Biografi (Proses Kejadian)}

Berdasarkan tabel diatas, kemampuan menulis teks biografi menunjukkan bahwa dari 81 siswa kelas X SMA Negeri 1 Lembo , sebanyak 80 siswa masuk kategori mampu dengan rincian 80 siswa memperoleh skor 4. Sedangkan 1 siswa masuk kategori tidak mampu dengan rincian 1 siswa memperoleh skor 1. Untuk lebih jelasnya dapat dilihat pada tabel berikut:

Tabel Persentase Perolehan Kemampuan Menulis Teks Biografi Tokoh Siswa Kelas X SMA Negeri 1 Lembo pada Aspek Struktur Teks Biografi (Proses Kejadian)

\begin{tabular}{|l|l|l|l|}
\hline No & Kategori & Frekuensi & Persentase \\
\hline 1. & Mampu & 80 & $98,76 \%$ \\
\hline 2. & $\begin{array}{l}\text { Tidak } \\
\text { Mampu }\end{array}$ & 1 & $1,23 \%$ \\
\multicolumn{2}{|c|}{ Jumlah } & 81 & $100 \%$ \\
\hline \multicolumn{2}{|c|}{ Selanjutnya untuk mengukur }
\end{tabular}

kemampuan menulis teks biografi tokoh pada aspek proses kejadian secara klasikal maka digunakan rumus sebagai berikut.

$100 \%$

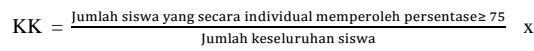

$$
\begin{array}{r}
K K=\frac{80}{81} \mathrm{X} 100 \% \\
=98,76 \%
\end{array}
$$

Berdasarkan persentase tersebut, dapat dikatakan bahwa siswa kelas $\mathrm{X}$ SMA Negeri 1 Lembo mampu dalam menulis teks biografi tokoh pada aspekproses kejadian. Dikatakan mampu, karena kemampuan siswa mencapai nilai rata-rata $98,76 \%$ atau berada pada standar yang ditentukan yakni antara 85-100\%.

\subsubsection{Kemampuan Menulis Teks}

\section{Biografi Tokoh Pada Aspek Struktur Teks Biografi \\ (Reorientasi)}

Berdasarkan hasil pengolahan data tentang kemampuan menulis teks biografi pada aspek struktur teks biografi (reorientasi) menunjukan bahwa dari 81 siswa yang menjadi sampel sebanyak $80(98,76 \%)$ yang secara individu dikategorikan mampu dan sebanyak $1 \quad(1,23 \%)$ siswa dikategorikan tidak mampu. Untuk lebih jelasnya dapat dilihat pada tabel berikut:

Tabel Persentase Kemampuan Menulis Teks Biografi Tokoh Siswa Kelas X SMA Negeri 1 Lembo pada Aspek Struktur Teks Biografi (Reorientasi)

\begin{tabular}{|l|l|l|l|}
\hline No & Kategori & Frekuensi & Persentase \\
\hline 1 & Mampu & 80 & $98,76 \%$ \\
\hline 2 & $\begin{array}{l}\text { Tidak } \\
\text { mampu }\end{array}$ & 1 & $1,23 \%$ \\
\hline \multicolumn{2}{|l|}{ Jumlah } & 81 & $100 \%$ \\
\hline
\end{tabular}


Selanjutnya untuk mengukur kemampuan menulis teks biografi tokoh pada aspek struktur biografi (reorientasi) secara klasikal maka digunakan rumusan sebagai berikut: $K K=\frac{80}{81} \mathrm{X} 100 \%=98,76 \%$

Berdasarkan

persentase tersebut, dapat dikatakan siswa kelas $\mathrm{X}$ SMA Negeri 1 Lembo mampu dalam menulis teks biografi tokoh pada aspek struktur teks biografi (reorientasi). Dikatakan mampu karena secara klasikal kemampuan siswa mencapai nilai rata-rata 98,76\% atau berada pada standar yang ditentukan yakni antara 85\%-100\%.

\subsubsection{Kemampuan Menulis Teks Biografi Tokoh pada Aspek Kebahasaan Teks Biografi (Pronomina)}

Berdarkan hasil pengolahan data tentang kempuan menulis teks biografi tokoh pada aspek kebahasaan teks biografi (Pronomina) menunjukkan bahwa dari 81 siswa yang menjadi sampel sebanyak 46 $(56,79 \%)$ yang secara individu dikategorikan belum mampu dan sebanyak $35 \quad(43,20 \%)$ siswa dikategorikan tidak mampu. Untuk lebih jelasnya dapat dilihat pada tabel berikut:

Tabel Persentase Kemampuan Menulis Teks Biografi Tokoh Siswa Kelas X SMA Negeri 1 Lembo pada Aspek Kebahasaan (Pronomina)

\begin{tabular}{|l|l|l|l|}
\hline No & Kategori & Frekuensi & Persentase \\
\hline 1 & Mampu & 46 & $56,79 \%$ \\
\hline 2 & $\begin{array}{l}\text { Tidak } \\
\text { mampu }\end{array}$ & 35 & $43,20 \%$ \\
\hline Jumlah & 81 & $100 \%$ \\
\hline \multicolumn{3}{|c|}{ Selanjutnya untuk mengukur } \\
kemampuan menulis teks biografi \\
tokoh pada aspek kebahasaan teks
\end{tabular}

biografi (pronominal) cara klasikal maka digunakan rumusan sebagai berikut:

$$
\begin{aligned}
\mathrm{KK} & =\frac{46}{81} \mathrm{X} 100 \% \\
& =56,79 \%
\end{aligned}
$$

Berdasarkan peresentase tersebut, dapat dikatakan siswa kelas X SMA Negeri 1 Lembo tidak mampu dalam menulis teks biografi pada aspek kebahasaan teks biografi (pronomina). Dikatakan tidak mampu kerena secara klasikal kemampuan siswa mencapai nilai rata-rata $56,79 \%$ atau tidak berada pada standar yang ditentukan yakni antara $85 \%-100 \%$.

\subsubsection{Kemampuan Menulis Teks Biografi Tokoh Pada Aspek Kebahasaan Teks Biografi (Kata Kerja Tindakan)}

Berdarkan hasil pengolahan data tentang kempuan menulis teks biografi tokoh pada aspek kebahasaan teks biografi (Pronomina) menunjukkan bahwa dari 81 siswa yang menjadi sampel sebanyak 49 $(60,49 \%)$ yang secara individu dikategorikan belum mampu dan sebanyak $32 \quad(39,50 \%)$ siswa dikategorikan tidak mampu. Untuk lebih jelasnya dapat dilihat pada tabel berikut:

Tabel Persentase Kemampuan Menulis

Teks Biografi Tokoh Siswa Kelas X

SMA Negeri 1 Lembo pada Aspek

Kebahasaan (Kata Kerja Tindakan)

\begin{tabular}{|l|l|l|l|}
\hline No & Kategori & Frekuensi & Persentase \\
\hline 1 & Mampu & 49 & $60,49 \%$ \\
\hline 2 & $\begin{array}{l}\text { Tidak } \\
\text { mampu }\end{array}$ & 32 & $39,50 \%$ \\
\hline \multicolumn{2}{|l|}{ Jumlah } & 81 & $100 \%$ \\
\hline
\end{tabular}

308 |Jurnal BASTRA (Bahasa dan Sastra), Vol. 4 No. 2, Edisi April 2019/e-ISSN: 2503-3875/ http://ojs.uho.ac.id/index.php/BASTRA 
Selanjutnya untuk mengukur kemampuan menulis teks biografi tokoh pada aspek kebahasaan teks biografi (kata kerja tindakan) cara klasikal maka digunakan rumusan sebagai berikut:

$$
\begin{array}{r}
\mathrm{KK}=\frac{49}{81} \mathrm{X} 100 \% \\
=60,49 \%
\end{array}
$$

Berdasarkan persentase tersebut, dapat dikatakan bahwa siswa kelas $\mathrm{X}$ SMA Negeri 1 Lembo belum mampu menulis teks biografi tokoh pada aspek kata kerja tindakan. Dikatakan belum mampu, karena kemampuan siswa mencapai $60,49 \%$ atau belum berada pada standar yang ditentukan yakni antara $85 \%-100 \%$.

\subsubsection{Kemampuan Menulis Teks Biografi Tokoh Pada Aspek Kebahasaan Teks Biografi (Kata Kerja Aktivitas)}

Berdarkan hasil pengolahan data tentang kempuan menulis teks biografi tokoh pada aspek kebahasaan teks biografi (kata kerja aktivitas) menunjukkan bahwa dari 81 siswa yang menjadi sampel sebanyak 12 $(14,81 \%)$ siswa yang secara individu dikategorikan mampu dan sebanyak 69(85,18\%) siswa dikategorikan tidak mampu. Untuk lebih jelasnya dapat dilihat pada tabel berikut:

Tabel Persentase Kemampuan Menulis Teks Biografi Tokoh Siswa Kelas X SMA Negeri 1 Lembo pada Aspek Kebahasaan (Kata Kerja Aktivitas)

\begin{tabular}{|l|l|l|l|}
\hline No & Kategori & Frekuensi & Persentase \\
\hline 1 & Mampu & 12 & $14,81 \%$ \\
\hline 2 & $\begin{array}{l}\text { Tidak } \\
\text { mampu }\end{array}$ & 69 & $85,18 \%$ \\
\hline
\end{tabular}

\begin{tabular}{|c|l|l|}
\hline Jumlah & 81 & $100 \%$ \\
\hline \multicolumn{2}{|c|}{ Selanjutnya untuk mengukur }
\end{tabular}

kemampuan menulis teks biografi tokoh pada aspek kebahasaan teks biografi (kata kerja aktivitas) cara klasikal maka digunakan rumusan sebagai berikut:

$$
\begin{array}{r}
\mathrm{KK}=\frac{12}{81} \mathrm{X} 100 \% \\
=14,81 \%
\end{array}
$$

Berdasarkan persentase tersebut ,dapat dikatakan siswa kelas X SMA Negeri 1 Lembo tidak mampu dalam menulis teks biografi pada aspek kebahasaan kata kerja aktivitas. Dikatakan tidak mampu karena secara klasikal kemampuan siswa mencapai nilai rata-rata $14,81 \%$ atau tidak berada pada standar yang ditentukan yakni $85 \%-100 \%$.

\subsubsection{Kemampuan Menulis Teks Biografi Tokoh Siswa Kelas X SMA Negeri 1 Lembo Pada Aspek Kebahasaan Teks Biografi (Konjungsi Kausalitas/Konjungsi Kronologis) \\ Berdarkan hasil pengolahan data} bahwa kemampuan siswa dari aspek konjungsi kausalitas/konjungsi kronologis dalam kemapuan menulis teks biografi tokoh siswa kelas $\mathrm{X}$ SMA Negeri 1 Lembo , di antara 81 siswa yang dijadikan sampel terdapat 76 siswa $(93,82 \%)$ yang termasuk kategori mampu dan terdapat 5 siswa $(6,17 \%)$ berada pada kategori tidak mampu dalam menulis teks biografi pada aspek kebahasaan konjungsi kausalitas dan konjungsi kronologis. 
Untuk lebih jelasnya dapat dilihat pada tabel berikut:

Tabel Persentase Kemampuan Menulis Teks Biografi Tokoh Siswa Kelas X SMA Negeri 1 Lembo Pada Aspek Kebahasaan (Konjungsi

Kausalitas/Konjungsi Kronologis)

\begin{tabular}{|l|l|l|l|}
\hline No & Kategori & Frekuensi & Persentase \\
\hline 1 & Mampu & 76 & $93,82 \%$ \\
\hline 2 & $\begin{array}{l}\text { Tidak } \\
\text { mampu }\end{array}$ & 5 & $6,17 \%$ \\
\hline \multicolumn{2}{|l|}{ Jumlah } & 81 & $100 \%$ \\
\hline
\end{tabular}

kemampuan menulis teks biografi tokoh pada aspek kebahasaan teks biografi (konjungsi kausalitas/ konjungsi kronologis) cara klasikal maka digunakan rumusan sebagai berikut:

$$
\begin{aligned}
\mathrm{KK} & =\frac{76}{81} \mathrm{X} 100 \% \\
& =93,82 \%
\end{aligned}
$$

Berdasarkan persentase tersebut, dapat dikatakan bahwa siswa kelas $\mathrm{X}$ SMA Negeri 1 Lembo mampu menulis teks biografi tokoh pada aspek kebahasaan konjungsi kausalitas/konjungsi kronologis . Dikatakan mampu, karena kemampuan siswa mencapai 93,82\% atau lebih dari batas kemampuan secara klasikal $85 \%$.

\subsection{Interpretasi Hasil Penelitian}

Berdasarkan deskripsi yang diperoleh informasi dari Sembilan aspek yang diteliti, aspek struktur orientasi ,struktur proses kejadian dan struktur reorientasi menduduki peringkat tertinggi dengan persentase kemampuan 98,76\%. Diikuti kemampuan pada aspek kebahasaan konjungsi kausalitas/ konjungsi kronologis dengan persentase 93,82 $\%$. Kemudian, aspek kebahasaan kata adjektiva dengan persentase $62,93 \%$, aspek kebahasaan kata kerja tindakan dengan persentase 60, aspek kebahasaan pronomina dengan persentase 56,79\%. Selajutnya , aspek kebahasaan kata kerja aktivitas $14,81 \%$. Kemudian aspek kebahasaan kata kerja pasif dengan persentase 9,87\%

Berdasarkan hasil tersebut dan analisis data secara klasikal dengan rumus statistik yang telah ditentukan, dapat diketahui bahwa secara keseluruhan (klasikal) kemampuan meringkas isi teks eksplanasi siswa kelas X SMA Negeri 1 Lembo adalah tidak mampu dengan persentase kemampuan $80,24 \%$. Dengan hasil yang dicapai tersebut siswa harus lebih giat lagi dalam proses belajar mengajar dan dengan hasil tersebut guru dapat memberikan motivasi lebih intensif lagi kepada siswa untuk terus belajar dalam rangka pencapaian tujuan pembelajaran secara optimal. Selain itu juga, hasil yang diperoleh dapat terus ditingkatkan lagi.

Seperti yang telah dijelaskan sebelumnya, penilaian menulis teks biografi tokoh yang ditulisoleh siswa berfokus pada empat aspek penilaian, yakni aspek struktur orientasi, struktur proses kejadian, struktur reorientasi, kebahasaan pronominal, kebahasaan kata kerja tindakan, kebahasaan kata adjaktiva, kebahsaan kata kerja pasif, kebahasaan kata kerja aktivitas, dan kebahasaan konjungsi kausalitas/ 
konjungsi kronologis. Masing-masing aspek terdiri dari empat indikator penilaiandan diberikan bobot penilaian yang telah ditetapkan peneliti. Temuan penelitian di lapangan sehubungan dengan aspek orientasi menunjukkan bahwa sebagian besar siswa mampu menulis sesuai dengan teks orientasi dengan baik. Hal ini terlihat dari perolehan persentasenilai dari keseluruhan siswa yaitu $98,76 \%$ dengan kategori mampu.Sebagian besar dari mereka mampu menulis teks biografi tanpa harus menambahkan kalimat yang tidak perlu untuk ditulis.

Pada aspek proses kejadian, hasil penilaian menunjukkan bahwa kemampuan siswa secara keseluruhan dikategorikan mampu yaitu dengan persentase nilai 98,76\%. Banyak siswa yang telah mampu menjelaskan "bagaimana" dan "mengapa" fenomena yang diangkat bias terjadi. Selanjutnya sehubungan dengan penilaian pada aspek reorientasi. Hasil penelitian menunjukkan bahwa kemampuan siswa dalam aspek reorientasi mampu. Persentase nilai secara keseluruhan pada aspek tersebut yaitu 98,76\% mampu . Sebagian besar dari mereka bisa membuat kesimpulan kalimat yang dituisnya.

Selanjutnya, aspek kebahasan pronominal. Hasil penilaian menunjukkan bahwa kemampuan siswa berkategori tidak mampu dengan persentase $56,79 \%$. Sebagian besar dari mereka hanya menuliskan kata ganti orang seperti ia dan beliau.
Selanjutnya, kemampuan siswa dalam aspek kebahasaan kata kerja tindakan berkategori tidak mampu dengan persentase $60,49 \%$, sebagian besar dari mereka belum mampu menggunakan kata kerja tindakan. Aspek kebahasaan kata adjaktiva berkategorikan tidak mampu dengan persentase 62,93\%, sebagian besar dari mereka belum bisa memahami menggunakan kata adjaktiva dengan tepat. Aspek kebahasaan kata kerja pasif berkategorikan tidak mampu dengan persentase $9,87 \%$, banyak siswa yang belum bisa menulis kata kerja pasif. Dengan demikian, secara keseluruhan sebagian besar siswa tidak mampu menjelaskan peristiwa yang dialami tokoh sebagai subjek yang diceritakan. Dan aspek kata kerja aktivitas berkategorikan tidak mampu dengan persentase $14,81 \%$, sebagian siswa belum bisa menulis kata kerja aktivita yang menjelaska mental dalam rangka penggambaran peran tokoh , kemudian aspek kebahasaan konjungsi kausaliatas/konjungsi kronologis yang menunjukkan bahwa sebagian besar siswa mampu menggunakan konjungsi kausalitas/ konjungsi kronologis secra tepat. Hal ini terlihat pada perolehan persentase nilai dari keseluruhan siswa yaitu 93,82\% dengan kategori mampu.

\section{PENUTUP}

\subsection{Kesimpulan}

Berdasarkan hasil analisis data, dapat disimpulkan bahwa dari 81 siswa yang menjadi sampel penelitian, terdapat 65 siswa $(80,24 \%)$ tergolong mampu 
menulisteks biografi tokoh, dan 16 siswa $(19,75 \%)$ tergolong tidak mampu dalammenulis teks biografi tokoh. Dengan demikian, dapat dikatakan bahwa siswa kelasX SMA Negeri 1 Lembo tidak mampu secara klasikal dalam menulis teks biografi dengan persentase kemampuan 80,24\%. Hal itu dapat dilihat dari hasil perolehan skor pada kesembilan aspek yang diteliti, kemampuan aspek struktur orientasi, diikuti kemampuan aspek struktur proses kejadian, diikuti kemampuan aspek struktur reorientasi 98,76\%. Kemudian, diikuti kemampuan pada aspek kebahasaan pronominal 56,79\%. Diikuti kemampuan pada aspek kebahasaan kata kerja tindakan dengan persentase $60,49 \%$, diikuti aspek kebahasaan kata adjektiva dengan persentase $62,93 \%$, aspek kebahasaan kata kerja pasif $9,87 \%$, diikuti kemampuan aspek kebahasaan kata kerja aktivitas denag persentase $14,81 \%$, dan terakhir kemampuan pada aspek kebahasaan konjungsi kausalitas/ konjungsi kronologis dengan persentase $93,82 \%$.

\subsection{Saran}

Berdasarkan rumusan simpulan yang telah dikemukakan di atas, penulis menyarankan beberapa hal sebagai berikut :

1. Guru bahasa Indonesia perlu memberikan dorongan terhadap siswa agar selalu mempertahankan kemampuan yang dimilikinya khususnya dalam menulis teks biografi.

2. Untuk mempelajari menulis teks biografi, guru dapat menyesuaikan ketuntasan materi dengan pemahaman siswa sehingga keseluruhan aspek-aspek dalam menulis teks biografi dapat di pahami oleh siswa.

3. Sebaiknya dilakukan penelitian lanjutan yang tidak dibicarakan dalam penelitian ini.

\section{DAFTAR PUSTAKA}

Abigail, W.A, Monica. 2015. Belajar Menulis. Surabaya: JP Books.

Arikunto, Suharsimi. 2002. Prosedur Penelitian Suatu Pendekatan Praktek. Jakarta: Rineka Cipta.

Djiwandono, M. Soenardi. 1996. Tea Bahasa dalam Pengajaran. Bandung: ITB.

Harahap, Syahrin. 2014. Metodologi Studi Tokoh \& Penulisan Biografi. Jakarta: PT Kharisma Putra Utama.

Harnila, Tika, dkk. 2016. Pengaruh Penggunaan Teknik Copy The Master Terhadap Keterampilan Menulis Teks Biografi Siswa Kelas X Sman 1 Painan Pesisir Selatan. Jurnal Pendidikan Bahasa Dan Sastra Indonesia, Vol. 6 No. 2 September 201.

Mahsun.2014. Teks Dalam Pembelajaran Bahasa Indonesia Kurikulum 2013. Jakarta: PT Rajagrafindo Persada.

Mulyati, Yeti, dkk. 2011. Bahasa Indonesia. Jakarta: Universitas Terbuka.

Nugraha, Pepih. 2013. Ranjau Biografi. Yogyakarta: PT Bentang Pustaka.

Priyatni, Endah Tri. 2017. Desain Pembelajaran Bahasa Indonesia dalam Kurikulum 2013. Jakarta: Bumi Aksara.

Putri, Mega dan Melia Rahmadona . (2014). Kemampuan Menulis Teks Biografi Siswa Kelas VIII SMP. Journal Bahastra, Oktober 2016, Volume XXXVI, Nomor1. 
Rosidi, Imron. 2009. Menulis Siapa Takut?. Yogyakarta: Kanisius

Sari, Elvi Yunita, dkk. 2017. Ibrahim Kadir, Biografi, Seniman, Gayo.

Jurnal Ilmiah Mahasiswa

Pendidikan Sejarah FKIP

Universitas Syiah Kuala Vol. 2,

Nomor 2, Maret 2017.

Sugiyono. 2016. Metode Penelitian

Kuantitatif, Kualitatif, dan $R \& D$.

Bandung: Alfabeta.

Suherli, dkk. 2017. Buku Guru Bahasa Indonesia Kelas X Revisi 2017. Jakarta: Kemendikbud.

Suherli, dkk. 2017. Buku Siswa Bahasa Indonesia Kelas X Revisi 2017. Jakarta: Kemendikbud.

Suparno, dan Mohamad Yunus. 2007. Keterampilan dasar menulis. Jakarta: Universitas Terbuka

Tarigan, Henry Guntur. 1984. Menulis Sebagai Suatu Keterampilan Bahasa. Bandung: Angkasa.

Wicaksono, Andri. 2014. Menulis Kreatif Sastra dan Beberapa Model Pembelajarannya. Yogyakarta: Garudhawaca 